\title{
Proposals to clarify and enhance the naming of fungi under the International Code of Nomenclature for algae, fungi, and plants ${ }^{1}$
}

\author{
David L. Hawksworth
}

Departamento de Biología Vegetal II, Facultad de Farmacia, Universidad Complutense de Madrid, Plaza Ramón y Cajal, Madrid 28040, Spain; Department of Life Sciences, The Natural History Museum, Cromwell Road, London SW7 5BD, UK; and Mycology Section, Royal Botanic Gardens, Kew, Richmond, Surrey TW9 3DS, UK; corresponding author e-mail: d.hawksworth@kew.org and d.hawksworth@nhm.ac.uk

\begin{abstract}
Twenty-three proposals to modify the International Code of Nomenclature for algae, fungi, and plants adopted in 2011 with respect to the provisions for fungi are made, in accordance with the wishes of mycologists expressed at the $10^{\text {th }}$ International Mycological Congress in Bangkok in 2014, and with the support of the International Commission on the Taxonomy of Fungi (ICTF), the votes of which are presented here. The proposals relate to: conditions for epitypification, registration of later typifications, protected lists of names, removal of exemptions for lichen-forming fungi, provision of a diagnosis when describing a new taxon, citation of sanctioned names, avoiding homonyms in other kingdoms, ending preference for sexually typified names, and treatment of conspecific names with the same epithet. These proposals are also being published in Taxon, will be considered by the Nomenclature Committee for Fungi and General Committee on Nomenclature, and voted on at the $19^{\text {th }}$ International Botanical Congress in Shenzhen, China, in 2017.
\end{abstract}

Article info: Submitted: 5 June 2015; Accepted: 10 June 2015; Published: 15 June 2015.

\section{INTRODUCTION}

Mycologists were gratified that the various changes in nomenclatural procedures relating to the treatment of fungal names that had been recommended by the $9^{\text {th }}$ International Mycological Congress (IMC9) in Edinburgh in August 2010 (Norvell et al. 2010) had subsequently been put to the 18th International Botanical Congress (IBC) in Melbourne in July 2011, acted on, and incorporated into the new edition of the Code, then re-named the International Code of Nomenclature for algae, fungi, and plants (ICN; McNeill et al. 2012). All the proposals that had been put forward were accepted, some after amendments, apart from one on governance that was referred to a newly formed Special Subcommittee on Governance of the Code with Respect to Fungi; that Subcommittee is to report separately and the issue consequently is not commented on further here. Further information on the changes pertinent to fungi enacted at the Melbourne IBC are summarized by Hawksworth (2011), and a record of the debates in the Nomenclature Section meetings is provided by Flann et al. (2014).

Subsequent to the 2011 IBC, various ways in which the rules could be further refined were compiled (Hawksworth

${ }^{1}$ The main text presented here is also being published in Taxon 64

(4): in press (August 2015) with some stylistic changes.
2014). These were presented to the "Genera and Genomes" symposium in Amsterdam in April 2014, where additional suggestions and modifications were made, and the essences distilled into 21 questions included in the packs of all delegates to the $10^{\text {th }}$ International Mycological Congress (IMC10) in Bangkok in August 2014. These proposals were discussed in three Nomenclature Sessions convened during IMC10, and a report of the Sessions and the opinions expressed in response to the questionnaire is provided by Redhead et al. (2014). At the conclusion of the Congress, the final plenary session, the General Assembly of the International Mycological Association (IMA), approved a Resolution requesting that the views expressed in the questionnaires be taken into account in formulating changes in the rules governing the nomenclature of fungi.

The proposals made here are in accordance with the IMC10 Resolution, and from further debates and discussions within the International Commission on the Taxonomy of Fungi (ICTF). The ICTF has 25 members who were asked to comment and vote on each proposal. The number voting was 21 , although not all voted on every question; the percentage voting "yes" and "no" are indicated in each case, with the number voting on that proposal given in squared parentheses. In some cases, the placement or precise wording of the proposals presented here has been amended from those voted on by the ICTF following consultations with the column editors. The substance of the proposals, however, remains unchanged.

() 2015 International Mycological Association

You are free to share - to copy, distribute and transmit the work, under the following conditions:

Attribution: $\quad$ You must attribute the work in the manner specified by the author or licensor (but not in any way that suggests that they endorse you or your use of the work).

Non-commercial: $\quad$ You may not use this work for commercial purposes.

No derivative works: You may not alter, transform, or build upon this work.

For any reuse or distribution, you must make clear to others the license terms of this work, which can be found at http://creativecommons.org/licenses/by-nc-nd/3.0/legalcode. Any of the above conditions can be waived if you get permission from the copyright holder. Nothing in this license impairs or restricts the author's moral rights. 
The proposals from the mycological community detailed here are now commended for adoption by the XIX IBC, to be held in Shenzhen, China, in July 2017.

In the proposed amendments detailed below, new text is given in bold type, and deleted text in strikethrough (strikethrough).

\section{PROPOSALS}

\section{Conditions for epitypification}

In order to be able to designate an epitype, Art. 9.8 requires that the existing type "is demonstrably ambiguous". It has been pointed out by Jørgensen (2014) that this phrase requires that attempts to recover DNA from a type have to be made, and fail, before the designation of a modern sequenced epitype can be justified. In many instances making such attempts is either impractical or prohibited, especially in the case of historic collections. For fungi, where molecular data are vital for the precise application of species names, this issue needs to be clarified in order to prevent many of the epitypfications proposed by mycologists in recent years being considered unsound. A few mycologists expressed unease about modifying the existing provision during the IMC10 Nomenclature Sessions (Redhead et al. 2014), but there was strong support in the questionnaire $\left(67.3 \% \mathrm{Y}^{2}\right)$ for permitting sequenced epitypes to be designated without having first to establish that DNA was not recoverable from the type they represent.

$$
\text { ICTF: Y (95\%), N (5\%) [21]. }
$$

\section{$(063)^{3}$ Amend Art. 9.8 as follows:}

"9.8. An epitype is a specimen or illustration selected to serve as an interpretative type when the holotype, lectotype, or previously designated neotype, or all original material associated with a validly published name, is dy and cannot, in the opinion of the author making the typification, be critically identified for purposes of the precise application of the name to a taxon. Designation of an epitype is not effected unless the holotype, lectotype or neotype that the epitype supports is explicitly cited (see Art. 9.20)."

\section{Registration of later typifications}

At present it is impossible to be sure whether a lectotype, neotype, or epitype has been designated as the type for a previously published name. There is currently no requirement for such nomenclatural acts to be recorded in a central repository, and typification acts have not been catalogued in the Index of Fungi. This is a particular problem in mycology as there is an increasing need to designate

\footnotetext{
${ }^{2} Y=$ Yes. See Redhead et al. (2014) for actual counts in all cases in which they are cited in this set of proposals.
}

${ }^{3}$ The proposal numbers adopted here are those in the version of this article in Taxon 64 (4): in press (August 2015). sequenced epitypes to fix the application of a name when molecular data are not available from the type. The "OneFungus = Which Name?" symposium in Amsterdam in 2012 unanimously supported the proposal that such typifications should be deposited in a database (Anon. 2012), and this suggestion was almost unanimously supported at IMC10 (95.2\% Y).

Two of the repositories recognized by the Nomenclature Committee for Fungi for the deposit of the information required for the valid publication of fungal names, Index Fungorum and MycoBank, have responded to this need; Index Fungorum issues a unique identifier, while MycoBank adds a "T" to the repository acronym (i.e. "MBT") preceding a number, although that is not a part of the identifier string itself. Many mycologists are already using this facility voluntarily, and many mycological journals now require information on such acts to be deposited in one of the official repositories as a part of their editorial policies. In order to make depositions of information on later typifications obligatory, this will need to be made a requirement for effective typification.

ICTF: Y (100 \%), N (0 \%) [20].

(064) Insert a new provision in Art. 7, preceding Note 2:

"7.11. For purposes of priority (Art. 9.19, 9.20, and 10.5), designation of a type, on or after 1 January 2019 , of the name of an organism treated as fungal under this Code (Pre. 8), is achieved only if an identifier (see Art. 42.2) issued by a recognized repository (see Art. 42.3) is cited."

If this proposal is accepted, then the Editorial Committee will need to add Art. 7.11 to the first sentence of Note 2 to make clear this provision relates to later typifications and not holotype designations.

(065) Insert a new paragraph in Art. 7 to follow Note 2:

“7.12. For an identifier required by Art. 7.11, the minimum elements of information that must be accessioned for type designations are the name being typified, the author designating the type, and those required by Art. 9.21, 9.22, and 9.23."

(066) Insert a new Note 3 in Art. 7 to follow the proposed new Art. 7.12:

"Note 3. Issuance of an identifier by a recognized
repository presumes subsequent fulfilment of
the requirements for effective type designation
(Art. 7.7-7.11) but does not in itself constitute a
type designation."

Epitypifications are not currently mentioned in Art. 9.23 and, for consistency with lecto- and neotypfications, the following amendment to that provision is proposed: 
(067) Amend Art. 9.23 as follows:

"9.23. On or after 1 January 2001, lectotypification, or-neotypification, or epitypification of a name of a species or infraspecific taxon, is not effected unless indicated by use of the term "lectotypus", er "neotypus", or "epitypus", its abbreviation, or its equivalent in a modern language (see also Art. 7.10 and 9.9)."

\section{Protected Lists of Names}

The ICN did not provide formal titles for the new lists of fungal names to be proposed for protection or rejection, and reference to them has become confused, especially with the conserved lists of names. "Protected vs. suppressed" was favoured by the Amsterdam symposium in 2013 (Anon. 2013) and overwhelmingly endorsed at IMC10 (88.4\% $Y$ votes). This pair of antonyms has the dual advantage of being distinctive and conveying in the titles the status of the listed names. If this change is accepted here, the Editorial Committee will need to avoid the use of "suppressed" as a synonym of "rejected" in Arts. 56.1 and 56.2, and in the title to App. V.

In order to grant the lists these titles, the following changes are proposed:

$$
\text { ICTF: Y (100\%), N (0 \%) [20]. }
$$

\section{(068) Amend Art. 14.13 as follows:}

"14.13. In the interests of nomenclatural stability, for organisms treated as fungi (including lichenicolous fungi, but excluding lichen-forming fungi and those fungi traditionally associated with them taxonomically, e.g. Mycocaliciaceae), lists of names may be submitted to the General Committee, which will refer them to the Nomenclature Committee for Fungi (see Div. III) for examination by subcommittees established by that Committee in consultation with the General Committee and appropriate international bodies. Protected Aceepted names on these lists, which become Appendices of the Code once reviewed and approved by the Nomenclature Committee for Fungi and the General Committee, are to be listed with their types together with those competing synonyms (including sanctioned names) against which they are treated as conserved (see also Art. 56.3)."

\section{(069) Amend Art. 56.3 as follows:}

"56.3. In the interests of nomenclatural stability, for organisms treated as fungi (including lichenicolous fungi, but excluding lichen-forming fungi and those fungi traditionally associated with them taxonomically, e.g. Mycocaliciaceae), lists of names to be rejeeted suppressed may be submitted to the General Committee, which will refer them to the Nomenclature Committee for Fungi (see Div. III) for examination by subcommittees established by that Committee in consultation with the General Committee and appropriate international bodies. Suppressed names on these lists, which become Appendices of the Code once reviewed and approved by the Nomenclature Committee for Fungi and the General Committee, are to be treated as rejected under Art. 56.1 and may become eligible for use only by conservation under Art. 14 (see also Art. 14.13)."

(070) Amend Art. 56.4 as follows:

"56.4. When a proposal for the rejection or suppression of a name under Art. 56 has been approved by the General Committee after study by the Committee for the taxonomic group concerned, rejection or suppression of that name is authorized subject to the decision of a later International Botanical Congress (see also Art. 14.16 and 34.2)."

\section{(071) Amend Rec. 56A as follows:}

"56A.1. When a proposal for the rejection or suppression of a name under Art. 56 has been referred to the appropriate Committee for study, authors should follow existing usage of names as far as possible, pending the General Committee's recommendation on the proposal (see also Rec. 14A and $34 \mathrm{~A}) . "$

Many fungal names have not been re-assessed since their introduction. In order to preclude the displacement of names now used by the resurrection of such forgotten names, for example by the discovery and re-examination of original material, or the designation of neo- or epitypes, mycologists have concluded that names accepted in the lists of protected names had to be safeguarded against all unlisted names in addition to any that might be given as synonyms or homonyms in the lists (Anon. 2013; Kirk et al. 2013). This need was supported by $88.6 \%$ Y at IMC10, and would avoid the need for proposals for conservation or rejection of names in the future as and when early little-used names were discovered. There are precedents for this: (1) in the protection accorded to the list of names in current use for Trichocomaceae (Pitt \& Samson 1993) by a special resolution passed at the Tokyo IBC in 1993 (Greuter et al. 1994: $\mathrm{x}$ ); (2) the protection afforded to sanctioned fungal names (see below); and (3) in the lists of conserved family names of bryophytes and spermatophytes in Appendix IIB of the ICN (Wiersema et al. 2015). In order to provide the required protection, the current wording needs to be amended, as at present it only refers to protection against listed competing synonyms. Further, if listed names are treated as protected against unlisted names, the obligation to cite known competing synonyms becomes superfluous, although it may be desirable to retain that option as it will be informative to users. The lists will need to be: (1) open for revision by successive congresses; and (2) subordinate to the lists of conserved names to cover instances where two or more names on the protected lists compete in different classifications and the later is preferred. The following proposals address these various requirements: 
(072) Amend Art. 14.13 as follows:

"14.13. In the interests of nomenclatural stability, for organisms treated as fungi (including lichenicolous fungi, but excluding lichen-forming fungi and those fungi traditionally associated with them taxonomically, e.g. Mycocaliciaceae), lists of names may be submitted to the General Committee, which will refer them to the Nomenclature Committee for Fungi (see Div. III) for examination by subcommittees established by that Committee in consultation with the General Committee and appropriate international bodies. Accepted Names on these lists, which become Appendices of the Code once reviewed and approved by the Nomenclature Committee for Fungi and the General Committee, are to be listed with their types and are treated as conserved against any competing listed or unlisted synonyms or homonyms (including sanctioned names) against which they are as conserved, although conservation under Art. 14 overrides this protection. Further, the lists of protected names remain open for revision through the procedures described above (see also Art. 56.3)."

(073) Amend Art. 14.16 as follows:

"14.16. When a proposal for the conservation or protection of a name has been approved by the General Committee after study by the Committee for the taxonomic group concerned, retention of that name is authorized subject to the decision of a later International Botanical Congress (see also Art. 14.13, 34.2, and 56.4)."

(074) Amend Rec. 14A.1 as follows:

"14A.1. When a proposal for the conservation or protection of a name has been referred to the appropriate Committee for study, authors should follow existing usage of names as far as possible pending the General Committee's recommendation on the proposal (see also Rec. 34A and 56A)."

\section{Removal of exemptions for lichen-forming fungi}

As lichen-forming fungi had traditionally been excluded from the provisions of the former Art. 59 permitting dual nomenclature, concern was expressed from the floor at the Melbourne Congress that the new Art. 57.2 could be de-stabilizing, and as a result the phrase "including lichenicolous fungi, but excluding lichen-forming fungi and those traditionally associated with them taxonomically, e.g. Mycocaliciaceae" was incorporated into Arts. 14.13, 56.3, and 57.2. With the deletion of Art. 57.2 proposed below, the remaining exceptions prohibit lists of names of lichen-forming fungi being proposed for protection or suppression. There are over 30 genera that include lichenized species as well as those with different biologies, some individual species may be lichenized or not, and it is not always clear whether a species is lichenized. Consequently, some species in the same genus may be eligible for protection while others would not. In addition, many orders and families include genera that are lichenized as well as genera that are not. These are biological issues and consequently they should not have a place in the ICN. Deletion of the exemptions was soon advocated (Anon. 2012, 2013, Kirk et al. 2013). At IMC10 there was overwhelming support for the rejection of these exceptions (89.4\% Y at IMC10), but while the congress was attended by around 60 lichenologists, it was unclear how many had completed the questionnaire. It was therefore felt that the views of the International Association for Lichenology (IAL) should also be sought, and this matter is being referred to the IAL Council for its opinion.

$$
\text { ICTF: Y (100\%), N (0\%) [19]. }
$$

(075) Amend the first sentence of Art. 14.13 (see Prop. 072) as follows:

"14.13. In the interests of nomenclatural stability, for organisms treated as fungi (ineluding lichenicolous fungi, but excluding lichen-forming fungi and those fungi traditionally associated with them taxonomically, e.g. Myeocalieiaceae), lists of names may be submitted to the General Committee, which will refer them to the Nomenclature Committee for Fungi (see Div. III) for examination by subcommittees established by that Committee in consultation with the General Committee and appropriate international bodies."

(076) Amend the first sentence of Art. 56.3 (see Prop. 069) as follows:

"56.3. In the interests of nomenclatural stability, for organisms treated as fungi (ineluding lichenicolous fungi, but exeluding lichen-forming fungi and those fungitraditionallyassociated with themtaxonomieally, e.g. Myeocalieiaceae), lists of names to be rejected may be submitted to the General Committee, which will refer them to the Nomenclature Committee for Fungi (see Div. III) for examination by subcommittees established by that Committee in consultation with the General Committee and appropriate international bodies.

(077) Instruct the Editorial Committee to delete the following words in Art. $\mathbf{5 7 . 2}$ in the event that Prop. (084) to delete that provision is not accepted:

\footnotetext{
“ fungi (ineluding lichenicolous fungi, but exeluding lichen-forming fungi and those fungi traditionally associated with them taxonomieally, e.g. Alyeocalieiaceae)"
}

\section{Diagnoses}

Prior to 1 January 2012, when a description or diagnosis in Latin was a mandatory requirement for the valid publication of a name of a new taxon, it was common practice to fulfil this requirement by providing a short diagnosis in Latin as well as 
a full description, generally in another language. Provision of a diagnosis, a statement of the characters distinguishing the new taxon from others, meant that the key features could easily be found without the need to analyse a lengthy description and any following discussion. Diagnoses have proved of such value to mycologists, that a new practice has been emerging now that Latin diagnoses are no longer mandatory: to have a short diagnosis in English as well as a full description. A replacement for Rec. $38 \mathrm{~B}$ is proposed to encourage this practice in naming new taxa not only in fungi but in all groups covered by the ICN.

$$
\text { ICTF: Y (81\%), N (19\%) [21]. }
$$

(078) Insert a new paragraph before Rec. 38B.1:

\begin{abstract}
"38B.1. When a description is provided for valid publication of the name of a new taxon, a separate diagnosis should also be presented.
\end{abstract}

(079) Revise the current Rec. 38.B.1 and renumber as follows:

"38.B.2. Where no separate diagnosis is provided, the description of any new taxon should mention the points in-which distinguish the taxon differs-from its allies others. "

\section{Citation of sanctioned names}

When the later starting points for the nomenclature of selected groups of fungi were abandoned at the Sydney IBC in 1981 and reverted to 1 May 1753, the concept of sanctioned names was introduced to protect names adopted in the former starting-point works against any competing names, whether treated in those works or not. There is no wish amongst mycologists to change that protection, and it has removed a need for countless conservation proposals. However, the use of the ":" in author citations to indicate the sanctioned status of names, which is recommended in the ICN (Rec. 50E.3) but is not obligatory, remains a cause of confusion. Almost 35 years after the introduction of this notation, sanctioned names are still commonly cited only with the author, bibliographic details, and date of the sanctioning work and not with the actual place and date of valid publication of the names. Also, not all authors use the notation today, because of the confusions that can result, including the key nomenclator database, Index Fungorum.

While there was only modest support for ending the use of the ":" in the IMC10 questionnaire $(71.8 \%)$, in the course of discussions in the Nomenclatural Sessions the suggestion of appending "nom. sanct." (nomen sanctum) in formal citations as an alternative was almost unanimously supported. This usage would parallel the use of other widely used indicators of nomenclatural status, for example, "nom. inval." and "nom. illeg.", after bibliographic references in full citations of names.

$$
\text { ICTF: Y (95\%), N (5\%) [20]. }
$$

(080) Amend Rec. 50E.3 as follows:

"50E.3. If a name has been adopted by Fries or Persoon, and thereby sanctioned (see Art. 13.1(d) and 15), ": Fr." or ": Pers." should be added in a formation the abbreviation "nom. sanct." (nomen sanctum) should be added in a formal citation, followed by the citation of the place of sanctioning if considered desirable. The same convention should be used for the basionym of the sanetioned name, if it has one, and for all combinations based on the sanctioned name or its basionym."

The reference to the sanctioning of basionyms adopted in the sanctioning works is proposed for deletion as under Art. 15 these are not sanctioned and so the existing Rec. 50E.3 was misleading.

(081) Instruct the Editorial Committee to revise Rec. 50E.3 Examples 6 and 7 if Proposal 080 is accepted.

The suggestion that the list of sanctioning works be extended to other works, especially comprehensive global monographic treatments, received limited support at IMC10 $(51.8 \% \mathrm{Y})$. In the event that a new Appendix of protected works is inserted into the Shenzhen Code in 2017 as a result of an additional proposal to be published separately, there will need to be a discussion as to whether the current sanctioning works should be included in such an Appendix. However, if proposal (072) is adopted, the nomenclatural protection given to names on the new lists of protected names would be the same as that already accorded to sanctioned names. However, the special rules regarding the typification of sanctioned names would not apply to protected names (Art. 9.10). It is therefore preferable to retain the distinction rather than replace "sanctioned" by "protected" throughout.

\section{Homonyms in other kingdoms}

The issue of identically spelled generic names in groups of organisms not covered by the $I C N$ is a problem for biologists in general. The Prokaryote [Bacterial] Code (Lapage et al. 1992), however, prohibits the use in prokaryotes of generic names already existing for algae, fungi, and protozoa. Rec. 54A of the ICN recommends that names existing in bacteriology and zoology be avoided when introducing new generic names under that Code. Now that interkingdom databases are becoming available, in particular the Catalogue of Life (http://www.catalogueoflife.org/), it is easier to check for homonyms in different groups than ever before. The issue was raised by Hawksworth (2014), but not included in the IMC10 questionnaire. Having considered the matter, the ICTF feels that some regulation in relation to microscopic organisms is desirable and should be introduced.

ICTF: Y (90\%), N (10\%) [20].

(082) Add a new clause to Art. 54.1 as follows:

“(c) A name published on or after 1 January 2019 for an alga or fungus is illegitimate if it is a later homonym of a bacterial or protozoan name." 
(083) Amend Rec. 54A.1 as follows:

"54A.1. Authors naming new plant taxa under this Code should, as far as is practicable, avoid using such names as already exist for zoological and bacteriological taxa."

\section{Ending precedence for sexually typified names}

Art. 57.2 aimed to ensure precedence for names typified by a sexual morph over names typified by asexual morphs, when the latter had priority by date of publication. It stated that in cases where both names were "widely used for a taxon", "an anamorph-typified name that has priority is not to displace the teleomorph name(s) unless and until a proposal to reject the former under Art. 56.1 or 56.3 or to deal with the latter under Art. 14.1 or 14.13 has been submitted and rejected". However, it has become clear that there is a general feeling among mycologists that sexually typified names should not have precedence if they do not have priority. There is no automatic penalty under the ICN for non-compliance with Art. 57.2, and the implication that an asexually typified name that has priority can only become correct by investing labour and time in publishing a formal proposal to reject or conserve a name that one does not want to be rejected or conserved is bizarre. There is also the subjective matter of when a name is to be considered "widely used", though some ways to obtain an indication of that have been proposed (Hawksworth 2012). With rare exceptions, such as the proposals by Samuels (2014) for names in Hypocrea, the formal route has been ignored by mycologists, and at IMC10 there was almost total support for the deletion of this provision $(93.0 \% \mathrm{Y})$.

$$
\text { ICTF: Y (95\%), N (5 \%) [19]. }
$$

(084) Delete Art. 57.2 and Ex. 2 and Ex. 3.

\section{Names with the same epithet}

From the Stockholm edition of the Code (Lanjouw et al. 1952) mycologists were prohibited from combining names with an asexual type into genera typified by as species with a sexual type. As mycologists were generally keen to retain the same species name when a sexual morph was discovered, a common practice was to use the same specific epithet for the newly discovered sexual morph. With the abandonment of dual nomenclature in 2011, the earliest available species name may not be the asexually typified name bearing the epithet used for the sexually typified name, but a littleknown asexually typified name long placed in synonymy. Alternatively, the asexually typified name bearing the epithet used for the sexually typified name may be the earliest legitimate species name, but not eligible for transfer as the binomial is pre-occupied. This is an unusual situation as the previous Codes had prevented mycologists from making new combinations when they found new sexual morphs of a known species; the rules had forced them to give new heterotypic names to what they recognized as morphs of a single species.

As the disruption of familiar names, especially of plant pathogens, due to this now obsolete requirement is clearly not in the interests of users of names, it has been suggested
(Hawksworth et al. 2013) that where mycologists used the same epithet for a newly discovered morph, those should be treated as new combinations and not as names of new species. This means that the material designated as the type of the sexual morph name would no longer have its previous nomenclatural status, though it would be available for designation as an epitype showing the sexual features if that was considered desirable. In principle, this idea received overwhelming support in the IMC10 questionnaire (86.9\%) amongst the 84 who voted on the question. This proposal is actually the converse of a situation already permitted under later Codes, which ruled that where asexually typified names were used as basionyms in sexually typified genera when the new morph was described, the intended combinations were to be treated as new species names and not new combinations despite the clear intent of the author.

Some members of the ICTF viewed this proposal negatively because they felt that these unwanted name changes could be avoided by placing desired names on a list of protected names. In addition they foresaw unintended problems if the type specimen of the name that was deemed to be a new combination was different from that of the basionym, i.e. the connection between the sexual and asexual morphs was not correct. Finally, they suggested that this provision would have a finite use as it was cleaning up an historical situation.

The connection, which subsequently proves to be erroneous, of a newly described morph with one already named parallels the publication of a new combination based on the study of material that later proves to belong to a different species.

$$
\text { ICTF: Y (67\%), N (33\%) [21]. }
$$

\section{(085) Insert a new provision in Art. 59:}

\begin{abstract}
"59.2. If, prior to 1 January 2013, an author publishing a new species name for the morph of a fungus that had an earlier name typified by a different morph adopted the specific epithet of the name of the previously described morph, the newly published name is to be treated as a new combination and not the name of a new taxon with a different type. Designations such as "sp. nov." and ascriptions excluding the earlier name are to be treated as formal errors requiring correction."
\end{abstract}

\section{ACKNOWLEDGEMENTS}

Mycologists are indebted to John McNeill for discussion and suggestions on the proposals prepared for consideration at IMC10, Franz Stadler, Nicholas J. Turland, and John H. Wiersema for insightful comments and refinements to wordings presented here, and Paul M. Kirk, Tom W. May, Scott A. Redhead, and ICTF members for helpful comments on earlier drafts. I would also like to acknowledge the use of the ICTF website and its content management system, which, in addition to serving as a complete publishing platform for related web content and data, also provided the means for discussion and voting on these proposals through the use of customized modules. 


\section{REFERENCES}

Anon. (2012) One Fungus = Which Name? IMA Fungus 3: (10)-(16). Anon. (2013) Progress on preparing lists of protected names. IMA Fungus 4: (3)-(4).

Flann C, Turland N, Monro AM (2014) Report on botanical nomenclature-Melbourne 2011. XVIII International Botanical Congress, Melbourne: Nomenclature Section, 18-22 July 2011. Phytokeys 41: 1-289.

Greuter W, Barrie FR, Burdet, HM Chaloner WG, Demoulin V, et al. (eds) (1994b) International Code of Botanical Nomenclature (Tokyo Code) adopted by the Fifteenth International Botanical Congress, Yokohama, August-September 1993. [Regnum Vegetabile No. 131.] Königstein: Koeltz Scientific Books.

Hawksworth DL (2011) A new dawn for the naming of fungi: impacts of decisions made in Melbourne in July 2011 on the future publication and regulation of fungal names. MycoKeys 1: 7-20; IMA Fungus 2: 155-162.

Hawksworth DL (2012) Managing and coping with names of pleomorphic fungi in a period of transition. Mycosphere 3: 52-64; IMA Fungus 3: 15-24.

Hawksworth DL (2014) Possible house-keeping and other draft proposals to clarify or enhance the naming of fungi within the International Code of Nomenclature for algae, fungi, and plants (ICN). IMA Fungus 5: 31-37.

Hawksworth DL, Crous PW, Redhead SA, Reynolds DR, Samson RA, Seifert KA, et al. (2011) The Amsterdam Declaration on Fungal Nomenclature. IMA Fungus 2: 105-112.

Hawksworth DL, McNeill J, de Beer, ZW, Wingfield MJ (2013) Names of fungal species with the same epithet applied to different morphs: how to treat them. IMA Fungus 4: 53-56.

Jørgensen PM (2014) Notes on the new Example 9 in Article 9.8 of the International Code of Nomenclature for algae, fungi, and plants. Taxon 63: 132-133.

Kirk PM, Stalpers JA, Braun U, Crous PW, Hansen K, et al. (2013) A without-prejudice list of generic names of fungi for protection under the International Code of Nomenclature for algae, fungi, and plants. IMA Fungus 4: 381-443.

Lanjouw J, Baehni C, Merrill ED, Rickett HW, Robyns W, et al. (eds) (1952) International Code of Botanical Nomenclature adopted by the Seventh International Botanical Congress, Stockholm, July 1950. [Regnum Vegetabile no. 3.] Utrecht: International Bureau for Plant Taxonomy.
Lapage SP, Sneath PHA, Lessel EF, Skerman VBD, Seeliger HPR, Clark WA (eds) (1992) International Code of Nomenclature for Bacteria. 1990 Revision. Washington DC: American Society for Microbiology.

McNeill J, Barrie FR, Buck WR, Demoulin V, Greuter W, et al. (eds) (2012) International Code of Nomenclature for algae, fungi, and plants (Melbourne Code) adopted by the Eighteenth International Botanical Congress Melbourne, Australia, July 2011. [Regnum Vegetabile No. 154.] Königstein: Koeltz Scientific Books.

Norvell LL, Hawksworth DL, Petersen RH, Redhead SA (2010) IMC9 Edinburgh Nomenclature Sessions. Mycotaxon 113: 503-511; IMA Fungus 1: 143-147.

Pitt JI, Samson RA (1993) Species names in current use in the Trichocomaceae (Fungi, Eurotiales). Regnum Vegetabile 128: 13-57.

Redhead SA, Demoulin V, Hawksworth DL, Seifert KA, Turland NJ (2014) Fungal nomenclature at IMC10: Report of the Nomenclature Sessions. IMA Fungus 5: 449-462.

Samuels GJ (2014) (2305-2309) Proposals to conserve the names Trichoderma catoptron against Hypocrea catoptron, $H$. sulfurella, and $H$. flavovirens; $T$. citrinoviride against Sphaeria schweinitzii (H. schweinitzii), S. contorta, $H$. repanda, and $H$. minima; $H$. lutea against Gliocladium deliquescens ( $T$. deliquescens) with a recommendation to reject the proposal (cf. Art. 57.2); $H$. pezizoides ( $T$. pezizoides) against $T$. pezizoideum; and T. reesei against $H$. jecorina (Ascomycota: Pezizomycotina: Sordariomycetes: Hypocreales: Hypocreaceae). Taxon 63: 936938.

Wiersma, JH, McNeill J, Turland NH, Barrie FR. Buck WR, et al. (eds). International Code of Nomenclature for algae, fungi, and plants (Melbourne Code) adopted by the Eighteenth International Botanical Congress Melbourne, Australia, July 2011: Appendices II-VIII. [Regnum Vegetabile No. 157.] Königstein: Koeltz Scientific Books. 